\title{
L-Lactic acid production from fructose by chitosan film-coated sodium alginate-polyvinyl alcohol immobilized Lactobacillus pentosus cells and its kinetic analysis
}

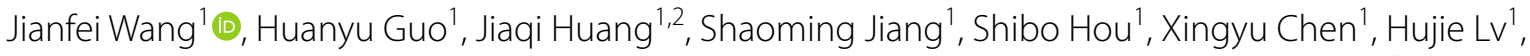
Xudong Bi ${ }^{1,3}$, Maolin Hou ${ }^{1,4}$, Hebei Lin ${ }^{1}$, Yuming Lu ${ }^{1}$, Jinyue Qiao ${ }^{1}$, Ruiyi Yang ${ }^{1}$ and Shijie Liu ${ }^{*}$

\author{
Abstract \\ Keywords: Cell immobilization, Kinetics, Optimization, Batch fermentation, Lactic acid
}

\section{Introduction}

Lactic acid (LA) is considered to be an important precursor for the synthesis of some oxygen-containing compounds and other chemical intermediates (Olszewska-Widdrat et al. 2019). In recent years, polylactic acid (PLA) has received extensive attention due to its biocompatibility and biodegradability, which has led to a further increase in the demand and production of LA (Agarwal et al. 1998; Abd Alsaheb et al. 2015). LA can be obtained through chemical synthesis or fermentation (Abdel-Rahman et al. 2011). Compared with the chemical synthesis that produces DL-LA racemic mixture as a by-product, fermentation by lactic acid bacteria (LAB) can produce L-LA or D-LA with high optical purity, thereby further reducing the cost of separation and purification of LA products (Zhao et al. 2016; Ricci et al. 2019).

The Lactobacillus pentosus (L. pentosus) is a suitable LAB to synthesize L-LA from different carbon sources by different fermentation types (Bustos et al. 2005). Generally, L. pentosus produces L-LA from hexose by

\footnotetext{
${ }^{*}$ Correspondence: sliu@esf.edu

${ }^{1}$ Department of Chemical Engineering, SUNY College of Environmental

Science and Forestry, Syracuse NY13210, USA

Full list of author information is available at the end of the article
}

homologous fermentation via the Embden-MeyerhoffParnas (EMP) pathway (Eq. (1)) or from pentoses by heterologous fermentation via the pentose phosphoketolase (PK) pathway (Eq. (2)) (Martinez et al. 2013; Mayo et al. 2010). However, L. pentosus can also synthesis L-LA from hexose by heterologous fermentation via the pentose phosphoketolase (PK) pathway (Eq. (3)) (Gao et al. 2011). The theoretical yields are $1 \mathrm{~g} / \mathrm{g}$ hexose, $0.6 \mathrm{~g} / \mathrm{g}$ pentosus, and $0.5 \mathrm{~g} / \mathrm{g}$ hexose, respectively.

$$
\begin{aligned}
& \mathrm{C}_{6} \mathrm{H}_{12} \mathrm{O}_{6} \rightarrow 2 \mathrm{C}_{3} \mathrm{H}_{6} \mathrm{O}_{3} \\
& \mathrm{C}_{5} \mathrm{H}_{10} \mathrm{O}_{5} \rightarrow \mathrm{C}_{3} \mathrm{H}_{6} \mathrm{O}_{3}+\mathrm{CH}_{3} \mathrm{COOH} \\
& \mathrm{C}_{6} \mathrm{H}_{12} \mathrm{O}_{6} \rightarrow \mathrm{C}_{3} \mathrm{H}_{6} \mathrm{O}_{3}+\mathrm{C}_{2} \mathrm{H}_{5} \mathrm{OH}+\mathrm{CO}_{2}
\end{aligned}
$$

Currently, cell immobilization technology is still a research hotspot. Cells immobilized by suitable materials have higher initial cell density and metabolic activity, thereby performing higher product yield and production rate (Kumar et al. 2014). Gel encapsulation is a common method of cell immobilization. During the cell immobilization process, the gel material reacts with the cross-linking agent to encapsulate the cells in the beads (Tang et al. 2017). Among various materials, sodium alginate (SA), 
polyvinyl alcohol (PVA), and chitosan (CS) have good properties and relatively low prices, which are ideal gel materials for cell immobilization. At present, the related studies still focus more on the immobilization by the single gel material. However, a single gel material is not suitable for all strains and fermentation conditions due to the specific properties of this material. The immobilized cell beads prepared from the mixture of two gel materials have also been studied, and the more common ones are SA-PVA beads and SA-CS beads. The SA-PVA bead has good surface properties and mechanical strength (Wang, Huang, Laffend et al. 2020a, b, c). However, the cell release from this type of beads cannot be effectively controlled. The SA-CS bead can effectively avoid cell release, but it has low mechanical strength and stability, resulting in a limited range of its applications due to the fermentation conditions. Jeon et al. (2019) studied the mechanical stability of both SA-CS beads and SA-PVA beads. They reported that SA-CS beads disintegrated at $1500 \mathrm{rpm}$ centrifugation, while SA-PVA beads could tolerate centrifugal speeds below $2000 \mathrm{rpm}$. Dong et al. (2017) also reported that SA-PVA beads have higher mechanical strength and activity recovery than SA-CS beads. Therefore, the SA-PVA immobilized cells coated with a CS film were used in the study, which could advantage of each material and avoiding the decrease in mass transfer efficiency and other properties of each material caused by the traditional immobilization method of mixing three materials as one gel mixture. In addition, fermentation conditions including the concentration of each gel material for preparing immobilized cell beads need to be considered to ensure the mass transfer efficiency of the beads and the metabolic activity of the cells. At present, the kinetic analysis of the fermentation by immobilized cells is still very limited. Therefore, establishing a suitable kinetic model can accurately and effectively describe the performance of immobilized cells.

In this study, the CS film-coated SA-PVA immobilized L. pentosus cells were used for L-LA production from fructose (FT) by batch fermentation. The conditions of immobilization and fermentation were optimized by Box-Behnken design. The effects of temperature and $\mathrm{pH}$ on the fermentation performance of CS film-coated SA-PVA immobilized cells, normal SA-PVA immobilized cells, and free cells were compared. The kinetics of cell growth, L-LA synthesis, and fructose consumption of three types of cells were also studied and compared. The performance of CS film-coated SA-PVA immobilized cells in repeated batch fermentation was discussed.

\section{Materials and methods}

Seed culture preparation

The freeze-dried L. pentosus ATCC 8041 strain obtained from the American Type Culture Collection (ATCC) was activated in de Man, Rogosa and Sharpe (MRS) medium for $20 \mathrm{~h}$ on a rotary shaker before batch fermentation. The temperature and shaking speed were controlled at $37^{\circ} \mathrm{C}$ and $150 \mathrm{rpm}$, respectively.

\section{Box-Behnken design}

Box-Behnken design was applied to optimize six selected parameters that were found to have significant effects in preliminary experiments based on Plackett-Burman design (Table 1). Single-factor preliminary experiments were applied to determine the range of each parameter for the highest LA yield and production rate, which can be selected for Box-Behnken design (data not shown).

\section{Cell immobilization}

The SA and PVA were dissolved in sterile deionized water at $30{ }^{\circ} \mathrm{C}$ and $80{ }^{\circ} \mathrm{C}$, respectively. Two gel solutions were then mixed for SA-PVA hydrogel with the specific concentration of each material. The concentrated seed culture with a volume of $5 \mathrm{ml}$ and a cell density of $3.08 \times 10^{8} \mathrm{CFU} / \mathrm{ml}(8.49 \log \mathrm{CFU} / \mathrm{ml})$ was injected into $100 \mathrm{ml}$ SA-PVA hydrogel solution and fully mixed by continuous stirring. The hydrogel solution containing cells was injected into the mixed cross-linking agent solution of $0.1 \mathrm{M} \mathrm{CaCl}_{2}$ and $2.5 \% \mathrm{H}_{3} \mathrm{BO}_{3}$ by a syringe to prepare immobilized cell beads with the diameter of

Table 1 The range of variables for L-LA fermentation of CS film-coated SA-PVA immobilized L. pentosus cells from FT

\begin{tabular}{|c|c|c|c|c|c|c|}
\hline \multirow[t]{2}{*}{ Factor } & \multirow[t]{2}{*}{ Variable } & \multirow[t]{2}{*}{ Code } & \multirow[t]{2}{*}{ Unit } & \multicolumn{3}{|c|}{ Level } \\
\hline & & & & -1 & 0 & +1 \\
\hline 1 & Sodium alginate concentration & $C_{S A}$ & $\%(w / v)$ & 1 & 3 & 5 \\
\hline 2 & Polyvinyl alcohol concentration & $C_{\text {PVA }}$ & $\%(w / v)$ & 4.0 & 5.5 & 7.0 \\
\hline 3 & Chitosan concentration & $\mathrm{C}_{\mathrm{CS}}$ & $\%(w / v)$ & 0.2 & 0.5 & 0.8 \\
\hline 4 & Fructose concentration & $C_{F T}$ & $g / L$ & 90 & 105 & 120 \\
\hline 5 & Temperature & $\mathrm{T}$ & ${ }^{\circ} \mathrm{C}$ & 31 & 35 & 39 \\
\hline 6 & $\mathrm{pH}$ & $\mathrm{pH}$ & & 5 & 6 & 7 \\
\hline
\end{tabular}


$2.2 \pm 0.5 \mathrm{~mm}$ (Wang et al. 2020a, b, c). The cross-linking process was conducted at $4{ }^{\circ} \mathrm{C}$ in a refrigerator for $4 \mathrm{~h}$. The CS solution with specific concentration was prepared by dissolving CS into the glacial acetic acid solution and adding $1 \mathrm{M} \mathrm{NaOH}$ solution to adjust $\mathrm{pH}$ to 5.6-6.0 (Zhou et al. 1998). The SA-PVA immobilized cell beads were washed by sterile deionized water and were subsequently immersed into the CS solution and stirred moderately on a shaker for $1 \mathrm{~h}$. The CS film-coated beads were then immersed into $0.3 \%$ glutaraldehyde solution and stirred moderately for $20 \mathrm{~min}$ at $\mathrm{pH} 5.4$ controlled by phosphate buffer. The concentration and treatment time of glutaraldehyde need to be strictly controlled to avoid damage to cell viability (Xu et al. 2012; Gür et al. 2018). The prepared CS film-coated SA-PVA immobilized cells were washed by sterile deionized water and stored in the peptone solution at $4{ }^{\circ} \mathrm{C}$. Before batch fermentation, the immobilized cells were activated in MRS medium for $8 \mathrm{~h}$.

\section{Batch fermentation}

The 1.0 L New Brunswick Bioreactor was used for batch fermentation with a working volume of $800 \mathrm{ml}$. The components in the fermentation medium are FT with a specific concentration, $4 \mathrm{~g} / \mathrm{L}$ yeast extract, $2 \mathrm{~g} / \mathrm{L} \mathrm{K}_{2} \mathrm{HPO}_{4}$, $2 \mathrm{~g} / \mathrm{L} \mathrm{KH}_{2} \mathrm{PO}_{4}$, and $0.78 \mathrm{~g} / \mathrm{L} \mathrm{MgSO}_{4}$. The fermentation temperature and $\mathrm{pH}$ were maintained at specific levels by the control system of the bioreactor. The stirring speed was controlled at $100 \mathrm{rpm}$ by a magnetic stirrer to avoid bead breakage caused by impellers. The airflow rate was maintained at $20 \mathrm{ml} / \mathrm{min}$. Repeated batch fermentation was carried out under optimized factors, while other conditions remain the same.

\section{Determination of cell concentration}

The $0.2 \mathrm{M}$ sodium citrate solution was used to dissolve beads for cell recycle. The weight concentration of encapsulated cells and released cells was determined based on the optical density (OD) at the wavelength of $600 \mathrm{~nm}$. The linear calibration curve was generated based on the linear relationship between OD values and standard cell solutions with a dry cell weight concentration. The trendline equation of this linear calibration curve was applied for the calculation of cell concentrations based on the corresponding OD values (Wang et al. 2020a, b, c). The solution of encapsulated cells with a dilution rate of $10^{-9}$ was cultivated on the MRS agar for the calculation of cell density in beads.

\section{Determination of fructose and LA concentrations}

The concentrations of fructose and LA were determined by proton nuclear magnetic resonance $\left({ }^{1} \mathrm{H}\right.$ NMR) spectroscopy. The NMR samples were mixed with $0.5 \mathrm{ml}$ supernatant of the centrifuged fermentation broth, $0.1 \mathrm{ml}$ internal standard, and $0.4 \mathrm{ml}$ deuterium oxide in $5-\mathrm{mm}$ o.d. NMR tubes. The internal standard consisted of $0.1 \%$ wt trimethylsilyl propionate, $0.2 \%$ wt trimethylamine, $4.2 \%$ wt glucosamine, and $95.5 \%$ wt deuterium oxide (Buyondo and Liu 2013). The MestReNova software was applied to integrate the peak areas of fructose and LA on the NMR spectrum. The trendline equation of the linear calibration curve generated based on the peak areas and standard solutions of substance concentrations were applied to calculate the concentrations of fructose and LA.

\section{Statistical analysis}

The Design Expert (Version 11) software was applied for experimental design and parametric optimization (Table 2). The Minitab software was applied for the calculation of $t$-statistics. The effects of all factors and their interactions on LA yield and LA production rate were described by response surface methodology (RSM). For box-Behnken design, a quadratic model would be generated as Eq. (4):

$$
y=c_{0}+\sum_{i=1}^{m} c_{i} x_{i}+\sum_{i=1}^{m} c_{i i} x_{i}^{2}+\sum_{i=1}^{m} \sum_{j=i+1}^{m} c_{i j} x_{i} x_{j},
$$

where $y, x_{i}$, and $x_{j}$ represent predicted responses, $i$ th factor, and $j$ th factor, respectively. Where as $c_{i}, c_{i i}$, and $c_{i j}$ represent coefficients of linear terms, quadratic terms, and interaction terms, respectively. The $c_{0}$ includes the offset constant and the random error (Agrawal et al. 2020).

\section{Kinetic analysis}

The ODEXLIMS function developed in Excel was applied to verify the adequacy of kinetic models and calculate the kinetic parameters by simultaneously solving the equations (Liu 2020). The Excel solver was applied to modify the kinetic parameters by minimizing the variance between the experimental data and predicted values.

\section{Results and discussions Result of NMR analysis}

The final components in the fermentation broth are represented by the peaks shown in the NMR spectrum (Fig. 1). The signal peak of fructose was observed at $4.12 \mathrm{ppm}$ corresponding to its $\mathrm{C} 3 \mathrm{H}-\beta, \mathrm{C} 4 \mathrm{H}-\beta$, and $\mathrm{C} 3 \mathrm{H}-\alpha$ (Cazor et al. 2006). The signal peak of LA was observed at $1.35 \mathrm{ppm}$ corresponding to its $\mathrm{C} 3 \mathrm{H}-\alpha$. The signal peak of glucosamine was observed at $5.45 \mathrm{ppm}$ corresponding to its $\mathrm{C} 1 \mathrm{H}-\alpha$ (Buyondo and Liu 2013). The signal peak of ethanol was not observed at 1.17 ppm (Fig. 1b), which 
Table 2 The LA yield and LA production rate of CS film-coated SA-PVA immobilized L. pentosus cells obtained under different treatments in batch fermentation from FT

\begin{tabular}{|c|c|c|c|c|c|c|c|c|}
\hline \multirow[t]{2}{*}{ Run } & \multicolumn{6}{|l|}{ Factor } & \multicolumn{2}{|l|}{ Response } \\
\hline & $\begin{array}{l}\text { Sodium alginate } \\
\text { concentration } \\
\mathrm{C}_{\mathrm{SA},} \%(\mathrm{~W} / \mathrm{V})\end{array}$ & $\begin{array}{l}\text { Polyvinyl alcohol } \\
\text { concentration } \\
C_{\text {PVA }^{\prime}} \%(\mathrm{~W} / \mathrm{v})\end{array}$ & $\begin{array}{l}\text { Chitosan } \\
\text { concentration } \\
\mathrm{C}_{\mathrm{CS}} \%(\mathrm{w} / \mathrm{v})\end{array}$ & $\begin{array}{l}\text { Fructose } \\
\text { concentration } \\
\mathrm{C}_{\mathrm{FT}}, \mathrm{g} / \mathrm{L}\end{array}$ & $\begin{array}{l}\text { Temperature } \\
\mathrm{T},{ }^{\circ} \mathrm{C}\end{array}$ & $\mathrm{pH}$ & $\begin{array}{l}\text { LA yield } \\
Y_{L A} g / g F T\end{array}$ & $\begin{array}{l}\text { LA production rate } \\
R_{L A^{\prime}} g /(L \times h)\end{array}$ \\
\hline 1 & 3 & 5.5 & 0.2 & 90 & 35 & 7 & $0.954 \pm 0.010$ & $2.338 \pm 0.018$ \\
\hline 2 & 3 & 7.0 & 0.5 & 105 & 39 & 7 & $0.975 \pm 0.005$ & $2.362 \pm 0.024$ \\
\hline 3 & 1 & 5.5 & 0.2 & 105 & 35 & 5 & $0.950 \pm 0.006$ & $2.340 \pm 0.027$ \\
\hline 4 & 5 & 5.5 & 0.2 & 105 & 35 & 5 & $0.959 \pm 0.008$ & $2.345 \pm 0.023$ \\
\hline 5 & 1 & 7.0 & 0.5 & 90 & 35 & 6 & $0.955 \pm 0.011$ & $2.322 \pm 0.022$ \\
\hline 6 & 5 & 7.0 & 0.5 & 120 & 35 & 6 & $0.968 \pm 0.005$ & $2.368 \pm 0.024$ \\
\hline 7 & 3 & 5.5 & 0.5 & 105 & 35 & 6 & $0.966 \pm 0.007$ & $2.420 \pm 0.019$ \\
\hline 8 & 3 & 5.5 & 0.5 & 105 & 35 & 6 & $0.969 \pm 0.006$ & $2.423 \pm 0.021$ \\
\hline 9 & 3 & 5.5 & 0.2 & 120 & 35 & 5 & $0.954 \pm 0.009$ & $2.327 \pm 0.025$ \\
\hline 10 & 1 & 5.5 & 0.5 & 120 & 31 & 6 & $0.958 \pm 0.009$ & $2.331 \pm 0.027$ \\
\hline 11 & 3 & 4.0 & 0.2 & 105 & 31 & 6 & $0.948 \pm 0.008$ & $2.336 \pm 0.024$ \\
\hline 12 & 5 & 5.5 & 0.5 & 120 & 39 & 6 & $0.970 \pm 0.006$ & $2.375 \pm 0.020$ \\
\hline 13 & 5 & 5.5 & 0.8 & 105 & 35 & 7 & $0.976 \pm 0.005$ & $2.330 \pm 0.023$ \\
\hline 14 & 5 & 5.5 & 0.5 & 90 & 31 & 6 & $0.956 \pm 0.011$ & $2.314 \pm 0.028$ \\
\hline 15 & 3 & 7.0 & 0.5 & 105 & 31 & 5 & $0.956 \pm 0.009$ & $2.299 \pm 0.029$ \\
\hline 16 & 5 & 4.0 & 0.5 & 120 & 35 & 6 & $0.968 \pm 0.007$ & $2.356 \pm 0.025$ \\
\hline 17 & 1 & 5.5 & 0.8 & 105 & 35 & 5 & $0.949 \pm 0.009$ & $2.327 \pm 0.024$ \\
\hline 18 & 3 & 7.0 & 0.8 & 105 & 39 & 6 & $0.968 \pm 0.006$ & $2.357 \pm 0.022$ \\
\hline 19 & 1 & 5.5 & 0.5 & 90 & 39 & 6 & $0.952 \pm 0.009$ & $2.342 \pm 0.021$ \\
\hline 20 & 3 & 4.0 & 0.8 & 105 & 39 & 6 & $0.968 \pm 0.007$ & $2.370 \pm 0.022$ \\
\hline 21 & 1 & 5.5 & 0.2 & 105 & 35 & 7 & $0.957 \pm 0.008$ & $2.356 \pm 0.027$ \\
\hline 22 & 5 & 5.5 & 0.5 & 90 & 39 & 6 & $0.959 \pm 0.009$ & $2.331 \pm 0.024$ \\
\hline 23 & 3 & 5.5 & 0.2 & 120 & 35 & 7 & $0.967 \pm 0.006$ & $2.343 \pm 0.028$ \\
\hline 24 & 3 & 4.0 & 0.2 & 105 & 39 & 6 & $0.956 \pm 0.010$ & $2.382 \pm 0.021$ \\
\hline 25 & 1 & 7.0 & 0.5 & 120 & 35 & 6 & $0.968 \pm 0.006$ & $2.333 \pm 0.024$ \\
\hline 26 & 3 & 4.0 & 0.5 & 105 & 39 & 7 & $0.963 \pm 0.005$ & $2.375 \pm 0.024$ \\
\hline 27 & 3 & 5.5 & 0.8 & 120 & 35 & 7 & $0.967 \pm 0.006$ & $2.341 \pm 0.026$ \\
\hline 28 & 3 & 4.0 & 0.8 & 105 & 31 & 6 & $0.961 \pm 0.007$ & $2.341 \pm 0.020$ \\
\hline 29 & 1 & 5.5 & 0.5 & 90 & 31 & 6 & $0.949 \pm 0.010$ & $2.325 \pm 0.028$ \\
\hline 30 & 5 & 5.5 & 0.8 & 105 & 35 & 5 & $0.964 \pm 0.009$ & $2.333 \pm 0.027$ \\
\hline 31 & 3 & 5.5 & 0.5 & 105 & 35 & 6 & $0.970 \pm 0.005$ & $2.420 \pm 0.019$ \\
\hline 32 & 3 & 7.0 & 0.2 & 105 & 39 & 6 & $0.961 \pm 0.008$ & $2.370 \pm 0.021$ \\
\hline 33 & 5 & 5.5 & 0.2 & 105 & 35 & 7 & $0.959 \pm 0.009$ & $2.343 \pm 0.028$ \\
\hline 34 & 3 & 5.5 & 0.5 & 105 & 35 & 6 & $0.974 \pm 0.005$ & $2.435 \pm 0.022$ \\
\hline 35 & 3 & 7.0 & 0.5 & 105 & 31 & 7 & $0.958 \pm 0.008$ & $2.315 \pm 0.027$ \\
\hline 36 & 1 & 5.5 & 0.5 & 120 & 39 & 6 & $0.969 \pm 0.005$ & $2.372 \pm 0.026$ \\
\hline 37 & 3 & 4.0 & 0.5 & 105 & 39 & 5 & $0.953 \pm 0.011$ & $2.341 \pm 0.026$ \\
\hline 38 & 3 & 5.5 & 0.8 & 90 & 35 & 7 & $0.961 \pm 0.007$ & $2.332 \pm 0.023$ \\
\hline 39 & 5 & 7.0 & 0.5 & 90 & 35 & 6 & $0.961 \pm 0.007$ & $2.306 \pm 0.027$ \\
\hline 40 & 3 & 7.0 & 0.2 & 105 & 31 & 6 & $0.960 \pm 0.006$ & $2.341 \pm 0.024$ \\
\hline 41 & 3 & 5.5 & 0.2 & 90 & 35 & 5 & $0.947 \pm 0.011$ & $2.322 \pm 0.024$ \\
\hline 42 & 3 & 4.0 & 0.5 & 105 & 31 & 5 & $0.950 \pm 0.008$ & $2.329 \pm 0.021$ \\
\hline 43 & 5 & 4.0 & 0.5 & 90 & 35 & 6 & $0.955 \pm 0.009$ & $2.320 \pm 0.029$ \\
\hline 44 & 3 & 5.5 & 0.5 & 105 & 35 & 6 & $0.970 \pm 0.006$ & $2.426 \pm 0.020$ \\
\hline 45 & 1 & 5.5 & 0.8 & 105 & 35 & 7 & $0.960 \pm 0.007$ & $2.343 \pm 0.021$ \\
\hline 46 & 3 & 5.5 & 0.8 & 120 & 35 & 5 & $0.961 \pm 0.008$ & $2.343 \pm 0.023$ \\
\hline
\end{tabular}


Table 2 (continued)

\begin{tabular}{|c|c|c|c|c|c|c|c|c|}
\hline \multirow[t]{2}{*}{ Run } & \multicolumn{6}{|l|}{ Factor } & \multicolumn{2}{|l|}{ Response } \\
\hline & $\begin{array}{l}\text { Sodium alginate } \\
\text { concentration } \\
\mathrm{C}_{\mathrm{SA}} \%(\mathrm{~W} / \mathrm{V})\end{array}$ & $\begin{array}{l}\text { Polyvinyl alcohol } \\
\text { concentration } \\
C_{\text {PVA, }^{\prime}} \%(W / v)\end{array}$ & $\begin{array}{l}\text { Chitosan } \\
\text { concentration } \\
\mathrm{C}_{\mathrm{CS},} \%(\mathrm{w} / \mathrm{v})\end{array}$ & $\begin{array}{l}\text { Fructose } \\
\text { concentration } \\
C_{\mathrm{FT}}, \mathrm{g} / \mathrm{L}\end{array}$ & $\begin{array}{l}\text { Temperature } \\
\mathrm{T}^{\circ}{ }^{\circ} \mathrm{C}\end{array}$ & $\mathrm{pH}$ & $\begin{array}{l}\text { LA yield } \\
Y_{L A}, g / g F T\end{array}$ & $\begin{array}{l}\text { LA production rate } \\
R_{L A^{\prime}} g /(L \times h)\end{array}$ \\
\hline 47 & 3 & 4.0 & 0.5 & 105 & 31 & 7 & $0.952 \pm 0.009$ & $2.327 \pm 0.028$ \\
\hline 48 & 3 & 7.0 & 0.8 & 105 & 31 & 6 & $0.967 \pm 0.006$ & $2.328 \pm 0.025$ \\
\hline 49 & 3 & 5.5 & 0.8 & 90 & 35 & 5 & $0.954 \pm 0.009$ & $2.298 \pm 0.026$ \\
\hline 50 & 1 & 4.0 & 0.5 & 90 & 35 & 6 & $0.949 \pm 0.010$ & $2.378 \pm 0.022$ \\
\hline 51 & 3 & 5.5 & 0.5 & 105 & 35 & 6 & $0.964 \pm 0.008$ & $2.426 \pm 0.023$ \\
\hline 52 & 1 & 4.0 & 0.5 & 120 & 35 & 6 & $0.962 \pm 0.007$ & $2.366 \pm 0.027$ \\
\hline 53 & 5 & 5.5 & 0.5 & 120 & 31 & 6 & $0.958 \pm 0.010$ & $2.316 \pm 0.020$ \\
\hline 54 & 3 & 7.0 & 0.5 & 105 & 39 & 5 & $0.959 \pm 0.009$ & $2.346 \pm 0.018$ \\
\hline
\end{tabular}

confirmed that the LA fermentation of $L$. pentosus from fructose was homologous.

\section{Regression model}

The quadratic regression models of LA yield and LA productivity are shown as Eq. (5) and Eq. (6), respectively.
The interaction of factors on each response The interaction of factors on LA yield

The LA yield increased significantly with the increase in both SA concentration and CS concentration (Fig. 2a). When the concentration of one gel material is low, the increase in the concentration of the other gel mate-

$$
\begin{aligned}
Y_{L A}= & 0.459432+0.003292 \times C_{\mathrm{SA}}+0.011139 \times C_{\mathrm{PVA}}+0.022315 \times C_{\mathrm{CS}} \\
& +0.002510 \times C_{\mathrm{FT}}+0.009396 \times T+0.039313 \times \mathrm{pH}+0.04167 \times C_{\mathrm{SA}} \\
& \times C_{\mathrm{CS}}+0.000035 \times C_{\mathrm{FT}} \times T+0.000687 \times T \times \mathrm{pH} \\
& -0.000635 \times C_{\mathrm{SA}}^{2}-0.000833 \times C_{\mathrm{PVA}}^{2}-0.023148 \times C_{\mathrm{CS}}^{2} \\
& -0.000016 \times C_{\mathrm{FT}}^{2}-0.000234 \times T^{2}-0.004958 \times \mathrm{pH}^{2}
\end{aligned}
$$

$$
\begin{aligned}
R_{\mathrm{LA}}= & -2.52559-0.008323 \times C_{\mathrm{SA}}+0.064486 \times C_{\mathrm{PVA}}+0.102222 \times C_{\mathrm{CS}}+0.024923 \times C_{\mathrm{FT}} \\
& +0.110807 \times T+0.466958 \times \mathrm{pH}+0.003625 \times C_{\mathrm{SA}} \times C_{\mathrm{PVA}}+0.000227 \times C_{\mathrm{SA}} \times C_{\mathrm{FT}} \\
& +0.000272 \times C_{\mathrm{PVA}} \times C_{\mathrm{FT}}+0.001222 \times C_{\mathrm{CS}} \times C_{\mathrm{FT}}+0.000137 \times C_{\mathrm{FT}} \times T-0.006250 \\
& \times C_{\mathrm{SA}}^{2}-0.009889 \times C_{\mathrm{PVA}}^{2}-0.244444 \times C_{\mathrm{CS}}^{2}-0.000152 \times C_{\mathrm{FT}}^{2}-0.001727 \times T^{2} \\
& -0.038375 \times \mathrm{pH}^{2} .
\end{aligned}
$$

Both regression models are significant with a model $\mathrm{p}$ value of less than 0.0001 (Tables 3 and 4). All terms shown in LA yield model are significant with a term $\mathrm{p}$ value of smaller than 0.05 . In the model of LA production rate, the $\mathrm{C}_{\mathrm{CS}} \times \mathrm{C}_{\mathrm{FT}}$ term has a minor influence on the result due to a $p$ value of larger than 0.05 but smaller than 0.1 , while other terms have significant influence. All these models are well fitted, which is confirmed by the non-significant values of "Lack of Fit". The high correlation coefficients $\left(R^{2}\right)$ with differences of smaller than 0.2 between adjusted and predicted $R^{2}$ confirms the high accuracy and reasonability of these models. The high adequate precision of larger than 4 and low coefficient of variation confirm the high adequacy and reliability of these models for the prediction of fermentation performance. rial has no significant effect on the improvement of LA yield. When the CS concentration was low, the cells in the beads could not be effectively encapsulated by the CS film. When the SA concentration was low, the mechanical strength of the beads was reduced, which led to the expansion and breakage of the beads, thus having a negative effect on the encapsulation performance of the beads (Gilson and Thomas 1995). Therefore, a low concentration of SA and CS would cause cell release. More substrate was consumed by these cells for cell growth in a larger space of fermentation medium, which resulted in a decrease in LA yield. High concentrations of SA and CS effectively encapsulated cells in beads, and the cell growth was inhibited, thereby increasing the conversion rate of substrates to LA. 


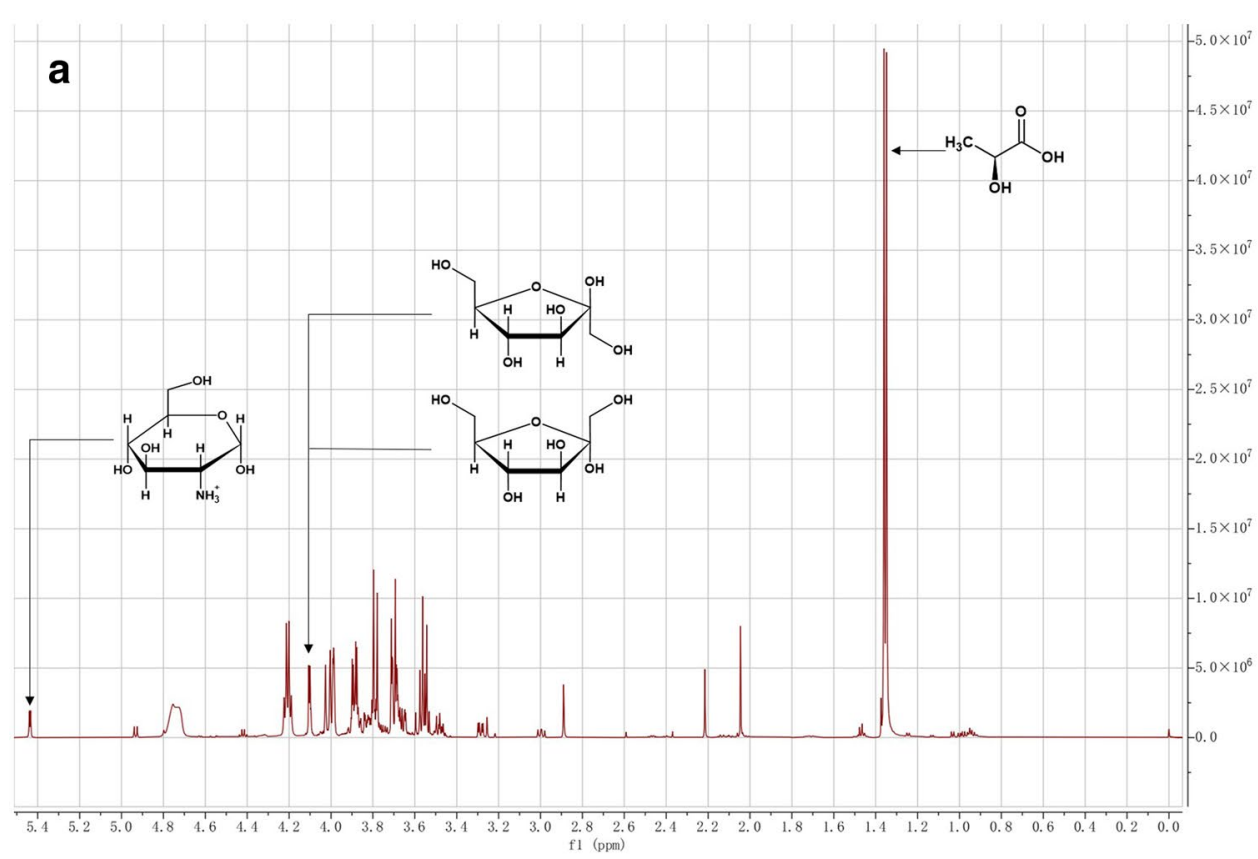

b

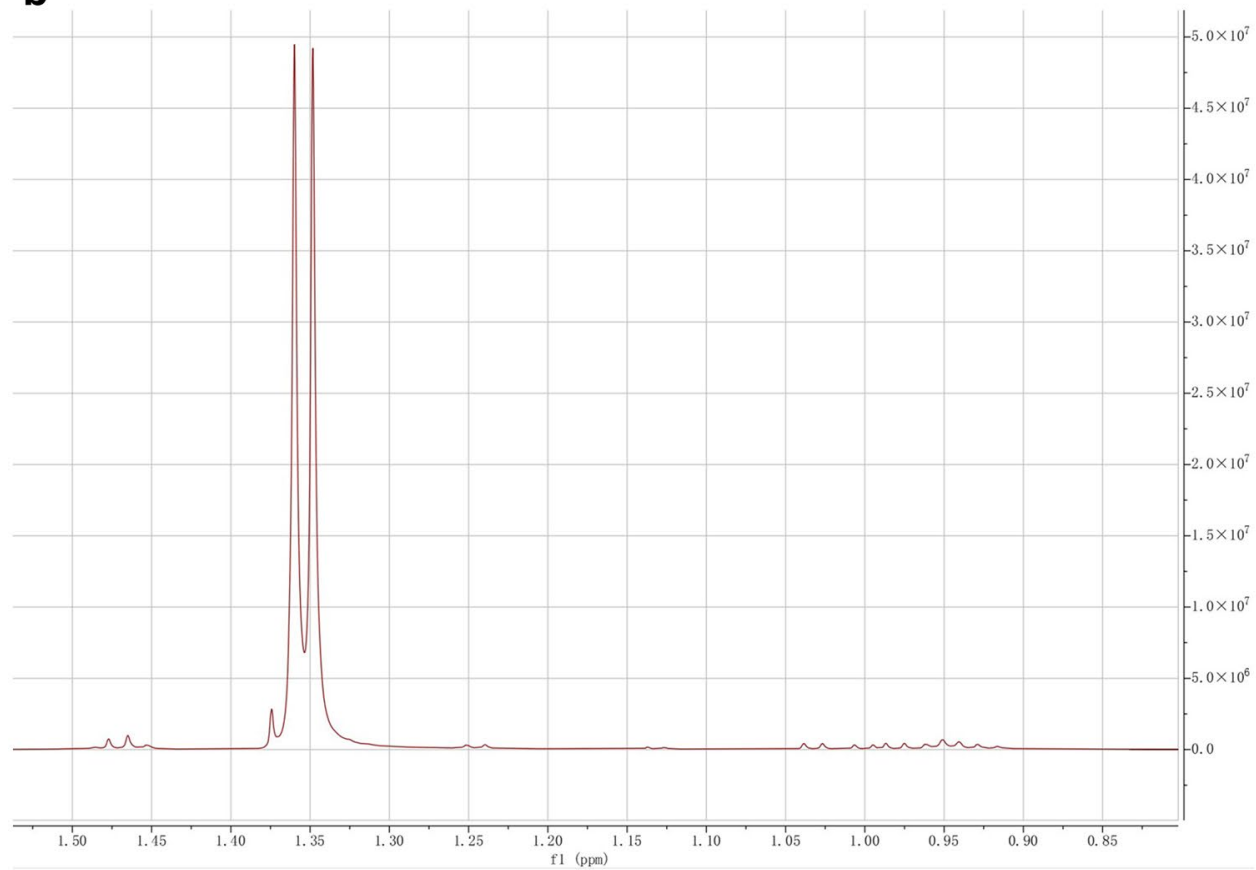

Fig. 1 a Signal peaks of LA, FT, and glucosamine on $1 \mathrm{H}$ NMR Spectrum. $\mathbf{b}$ The $1 \mathrm{H}$ NMR spectrum from 0.85 ppm to 1.50 ppm

Therefore, when the concentration of one gel material is higher, the increase in the concentration of the other gel material can significantly increase the LA yield.

The interaction of temperature and sugar concentration on LA yield is also very significant (Fig. 2b). When the temperature was low, the growth activity of the cells was higher, so more substrate was consumed for cell growth, resulting in low LA yield (Llamas et al. 2020). The increase in the cell content in the beads will also cause further limitations on the efficiency of substrate transport and metabolite synthesis (Wang et al. 2010). Therefore, when the temperature was low, the LA yield 
Table 3 The ANOVA for LA yield of CS film-coated SA-PVA immobilized L. pentosus cells

\begin{tabular}{|c|c|c|c|c|c|}
\hline Source & Sum of squares & Degree of freedom & Mean square & Fvalue & $p$ value \\
\hline Model & 0.0026 & 15 & 0.0002 & 19.98 & $<0.0001$ \\
\hline$C_{S A}$ & 0.0002 & 1 & 0.0002 & 26.69 & $<0.0001$ \\
\hline$C_{\text {PVA }}$ & 0.0002 & 1 & 0.0002 & 23.92 & $<0.0001$ \\
\hline$C_{C S}$ & 0.0003 & 1 & 0.0003 & 33.48 & $<0.0001$ \\
\hline$C_{F T}$ & 0.0006 & 1 & 0.0006 & 66.06 & $<0.0001$ \\
\hline $\mathrm{T}$ & 0.0003 & 1 & 0.0003 & 30.37 & $<0.0001$ \\
\hline $\mathrm{pH}$ & 0.0004 & 1 & 0.0004 & 41.30 & $<0.0001$ \\
\hline $\mathrm{C}_{S \mathrm{~A}} \times \mathrm{C}_{\mathrm{CS}}$ & 0.0000 & 1 & 0.0000 & 5.69 & 0.0221 \\
\hline$C_{F T} \times T$ & 0.0000 & 1 & 0.0000 & 4.11 & 0.0496 \\
\hline $\mathrm{T} \times \mathrm{pH}$ & 0.0001 & 1 & 0.0001 & 6.89 & 0.0124 \\
\hline$C_{S A}^{2}$ & 0.0001 & 1 & 0.0001 & 7.57 & 0.0091 \\
\hline$C_{P V A}{ }^{2}$ & 0.0000 & 1 & 0.0000 & 4.12 & 0.0495 \\
\hline $\mathrm{C}_{\mathrm{CS}}{ }^{2}$ & 0.0000 & 1 & 0.0000 & 5.08 & 0.0300 \\
\hline $\mathrm{C}_{\mathrm{FT}}^{2}$ & 0.0001 & 1 & 0.0001 & 15.75 & 0.0003 \\
\hline $\mathrm{T}^{2}$ & 0.0001 & 1 & 0.0001 & 16.47 & 0.0002 \\
\hline $\mathrm{pH}^{2}$ & 0.0003 & 1 & 0.0003 & 28.80 & $<0.0001$ \\
\hline Residual & 0.0003 & 38 & $8.782 \times 10^{-6}$ & & \\
\hline Lack of Fit & 0.0003 & 33 & $8.269 \times 10^{-6}$ & $0.6769^{*}$ & 0.7743 \\
\hline Pure Error & 0.0001 & 5 & 0.0000 & & \\
\hline Cor Total & 0.0030 & 53 & & & \\
\hline Standard deviation & 0.0030 & & $R^{2}$ & 0.8875 & \\
\hline Mean & 0.9604 & & Adjusted $R^{2}$ & 0.8430 & \\
\hline Coefficient of variation (C.V.\%) & 0.3085 & & Predicted $\mathrm{R}^{2}$ & 0.7692 & \\
\hline Press & 0.0007 & & Adequate precision & 16.4541 & \\
\hline
\end{tabular}

*Non-significant at $5 \%$ level

could be increased due to a small increase in the FT concentration, but it was not improved significantly with the further increase in FT due to the higher cell density in the beads. As the temperature increases, the LA synthesis activity of cells was gradually enhanced, thereby promoting LA yield. In a suitable temperature range, an increase in the FT concentration resulted in an increase in the net conversion rate of the substrate to LA under cell growth inhibition, which led to a further improvement in LA yield. When the temperature further increased, the metabolic activity of cells was inhibited, and more substrate was consumed for cell maintenance, which caused a reduction in the conversion rate of the substrate to LA, thereby resulting in a decrease in LA yield (Thakur et al. 2018; Sridevi et al. 2015).

The interaction of temperature and $\mathrm{pH}$ on LA yield is mainly related to their combined effect on the activity of enzymes that regulate cell growth and metabolism (Hansen et al. 2016). Lower or higher $\mathrm{pH}$ will adversely affect LA yield at lower or higher temperatures (Fig. 2c). When one factor is in the suitable range, an appropriate increase in the other factor could significantly improve the LA yield, but its further increase would lead to a decrease in the LA yield.

\section{The interaction of factors on $L A$ production rate}

The effects of SA concentration and PVA concentration on LA production rate showed a parabolic behavior (Fig. 3a). As the main gel material for immobilized cell beads, the concentration of SA and PVA has a significant impact on the shape, structure, and mass transfer efficiency of immobilized cell beads. Lower concentrations of SA or PVA would result in a significant decrease in the mechanical strength and surface properties of the beads, which caused shape changes of the beads or even disintegration, thereby resulting in a decrease in fermentation efficiency due to changes in the internal environment of the beads and cell release (Bhatnagar et al. 2016). When the concentration of SA or PVA was higher, the denser structure and reduced surface properties of the beads create greater resistance to the transfer of substrates and nutrients into the bead, thereby negatively affecting the fermentation efficiency (Najafpour et al. 2004). Therefore, the concentrations of both SA and PVA must be 
Table 4 The ANOVA for LA production rate of CS film-coated SA-PVA immobilized L. pentosus cells

\begin{tabular}{|c|c|c|c|c|c|}
\hline Source & Sum of squares & Degree of freedom & Mean square & Fvalue & $p$ value \\
\hline Model & 0.0563 & 17 & 0.0033 & 48.84 & $<0.0001$ \\
\hline$C_{S A}$ & 0.0004 & 1 & 0.0004 & 5.91 & 0.0202 \\
\hline$C_{P V A}$ & 0.0013 & 1 & 0.0013 & 18.62 & 0.0001 \\
\hline$C_{C S}$ & 0.0004 & 1 & 0.0004 & 6.15 & 0.0181 \\
\hline$C_{F T}$ & 0.0025 & 1 & 0.0025 & 36.31 & $<0.0001$ \\
\hline $\mathrm{T}$ & 0.0074 & 1 & 0.0074 & 108.98 & $<0.0001$ \\
\hline $\mathrm{pH}$ & 0.0010 & 1 & 0.0010 & 14.77 & 0.0005 \\
\hline$C_{S A} \times C_{P V A}$ & 0.0009 & 1 & 0.0009 & 13.96 & 0.0006 \\
\hline$C_{S A} \times C_{F T}$ & 0.0007 & 1 & 0.0007 & 10.96 & 0.0021 \\
\hline$C_{P V A} \times C_{F T}$ & 0.0003 & 1 & 0.0003 & 4.43 & 0.0424 \\
\hline$C_{C S} \times C_{F T}$ & 0.0002 & 1 & 0.0002 & 3.57 & 0.0669 \\
\hline$C_{F T} \times T$ & 0.0005 & 1 & 0.0005 & 8.04 & 0.0075 \\
\hline$C_{S A}^{2}$ & 0.0064 & 1 & 0.0064 & 94.87 & $<0.0001$ \\
\hline$C_{P V A}{ }^{2}$ & 0.0051 & 1 & 0.0051 & 75,14 & $<0.0001$ \\
\hline $\mathrm{C}_{\mathrm{CS}^{2}}$ & 0.0050 & 1 & 0.0050 & 73.46 & $<0.0001$ \\
\hline $\mathrm{C}_{\mathrm{FT}}^{2}$ & 0.0120 & 1 & 0.0120 & 176.76 & $<0.0001$ \\
\hline$T^{2}$ & 0.0078 & 1 & 0.0078 & 115.83 & $<0.0001$ \\
\hline $\mathrm{pH}^{2}$ & 0.0151 & 1 & 0.0151 & 223.53 & $<0.0001$ \\
\hline Residual & 0.0024 & 36 & 0.0001 & & \\
\hline Lack of Fit & 0.0023 & 31 & 0.0001 & $2.36^{*}$ & 0.1713 \\
\hline Pure Error & 0.0002 & 5 & 0.0000 & & \\
\hline Cor Total & 0.0587 & 53 & & & \\
\hline Standard deviation & 0.0082 & & $R^{2}$ & 0.9584 & \\
\hline Mean & 2.35 & & Adjusted $R^{2}$ & 0.9388 & \\
\hline Coefficient of variation (C.V.\%) & 0.3503 & & Predicted $R^{2}$ & 0.8872 & \\
\hline Press & 0.0066 & & Adequate precision & 25.4066 & \\
\hline
\end{tabular}

* Non-significant at $5 \%$ level

controlled within a suitable range to obtain a higher LA production rate.

The influence of the concentration of each gel material and the concentration of FT on the LA production rate also showed a parabolic trend (Fig. 3b-d). The effect of the concentration of each gel material on the LA production rate was still related to the cell viability, mass transfer efficiency, and cell encapsulation performance of the beads affected by the shape, morphology, structural compactness, and surface properties. When the FT concentration is low, cell growth and metabolism were not fully stimulated, which resulted in a decrease in fermentation efficiency due to a lower amount and viability of cells (Bahry et al. 2019). Therefore, an appropriate increase in the FT concentration could increase the difference in FT concentration inside and outside the beads, which would improve the diffusion efficiency of FT into the beads, thereby increasing the LA production rate. When the sugar concentration further increased, the LA production rate decreased slightly, which might be related to the decrease in cell metabolism rate caused by the reduction in water activity in the environment of high FT concentration (Tapia et al. 2020).

The combined effect of temperature and FT concentration on LA production rate was similar to that on LA yield, which was mainly related to the activity of cell growth and metabolism influenced by these two factors. When one factor was at a low level, the promotion of the other factor could not significantly improve the fermentation efficiency (Fig. 3e). When both factors were at a high level, the LA production rate was slightly inhibited, but it could still be maintained at a high level. In addition, when the concentration of the substrate was high, a proper increase in temperature could promote the substrate transport, thereby increasing the utilization and conversion efficiency of the substrate by cells (Vidgren et al. 2010). Therefore, an appropriate increase in both FT concentration and temperature could effectively increase the LA synthesis efficiency of cells. 


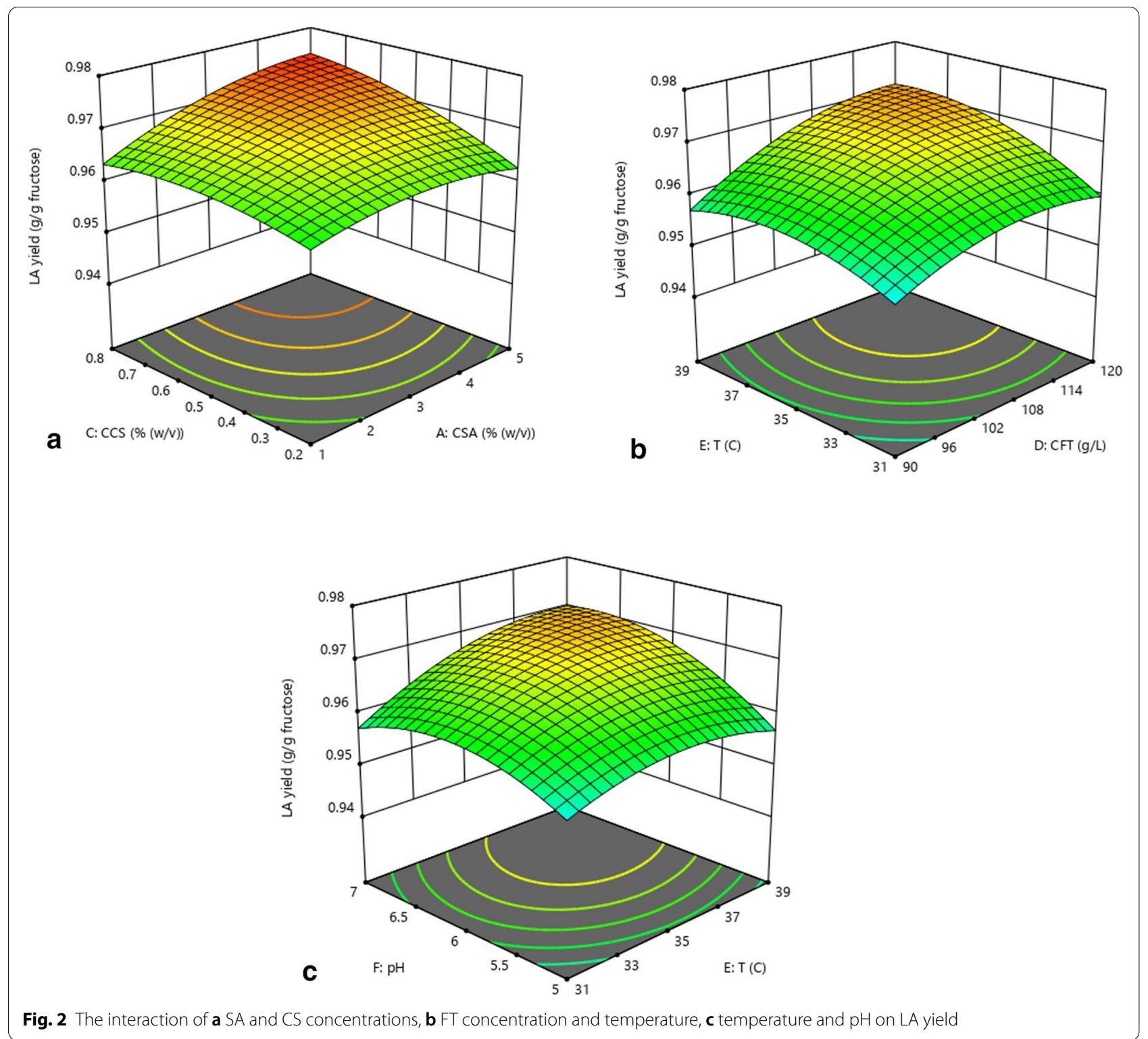

\section{Optimization and validation test}

By maximizing LA yield and production rate simultaneously, the predicted highest LA yield of $0.971 \mathrm{~g} / \mathrm{g}$ fructose and highest LA production rate of $2.430 \mathrm{~g} /(\mathrm{L} \times \mathrm{h})$ were obtained at estimated optimal gel material concentrations of $2.809 \%(\mathrm{w} / \mathrm{v}) \mathrm{SA}, 5.253 \%(\mathrm{w} / \mathrm{v})$ PVA, and $0.478 \%$ $(\mathrm{w} / \mathrm{v}) \mathrm{CS}$, and estimated fermentation conditions of $107.396 \mathrm{~g} / \mathrm{L} \mathrm{FT}, 36.363{ }^{\circ} \mathrm{C}$, and $\mathrm{pH}$ 6.084. The validation test was carried out under these optimized conditions. Other conditions are maintained in accordance with previous experiments. The experimental results of LA yield and production rate were obtained as $0.966 \pm 0.006 \mathrm{~g} / \mathrm{g}$ fructose and $2.426 \pm 0.018 \mathrm{~g} /(\mathrm{L} \times \mathrm{h})$, respectively. The errors of LA yield and LA production rate were $-0.5 \%$ and $-0.2 \%$, respectively, which confirms the accuracy and reliability of the prediction for fermentation performance and the estimation for optimal conditions. Radosavljević et al. (2020) obtained the highest LA yield of $97.6 \%$ and the highest production rate of $0.8 \mathrm{~g} /(\mathrm{L} \times \mathrm{h})$ in the batch fermentation with PVA/Ca-alginate immobilized L. rhamnosus cells. Bahry et al. (2019) used the alginate immobilized L. rhamnosus cells for LA production from carob pod waste and obtained the highest LA yield and highest production rate of $76.9 \%$ and $1.22 \mathrm{~g} /(\mathrm{L} \times \mathrm{h})$, 

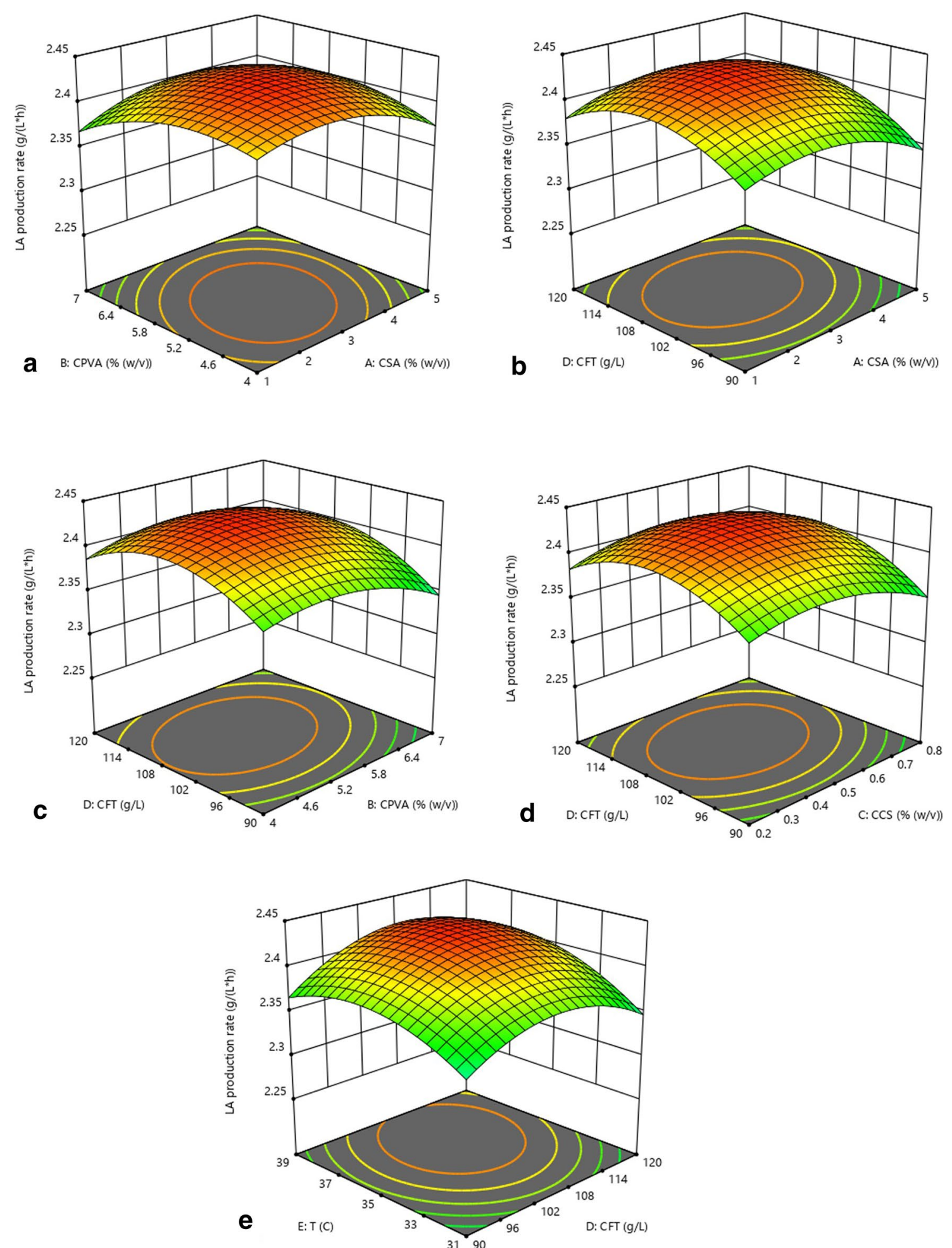

Fig. 3 The interaction of $\mathbf{a}$ SA and PVA concentrations, $\mathbf{b}$ SA and FT concentrations, $\mathbf{c}$ PVA and FT concentrations, $\mathbf{d}$ CS and FT concentrations, e FT concentration and temperature on LA production rate 
respectively. Thakur et al. (2018) obtained the highest LA yield of $0.921 \mathrm{~g} / \mathrm{g}$ substrate and the highest LA production rate of $2.28 \mathrm{~g} /(\mathrm{L} \times \mathrm{h})$ in the batch fermentation with SA-CS immobilized L. casei cells.

\section{Fermentation performance of CS film-coated SA-PVA immobilized cells, normal SA-PVA immobilized cells, and free cells \\ Comparison of $L A$ yield and $L A$ production rate of three types of cells at optimized conditions}

The conditions for normal SA-PVA immobilized cells and free cells were also optimized based on Box-Behnken design. The normal SA-PVA immobilized cell bead was also prepared by optimized gel material concentrations of $2.203 \%(\mathrm{w} / \mathrm{v})$ SA and $6.328 \%(\mathrm{w} / \mathrm{v})$ PVA. The batch fermentation was conducted at the optimal conditions of $112.339 \mathrm{~g} / \mathrm{L} \mathrm{FT}, 35.731{ }^{\circ} \mathrm{C}$, and $\mathrm{pH}$ 5.914. The batch fermentation of free cells was conducted at $109.167 \mathrm{~g} / \mathrm{L} \mathrm{FT}$, $34.592{ }^{\circ} \mathrm{C}$, and $\mathrm{pH}$ 6.132. The LA yield and production rate of CS film-coated SA-PVA immobilized L. pentosus cells were significantly higher than that of no CS filmcoated SA-PVA immobilized cells and free cells (Tables 5, $6)$.

\section{Comparison of LA yield and LA production rate of three types of cells at different temperature}

In the selected temperature range, the LA yield and LA production rate of immobilized cells are relatively stable (Fig. 4a, b). When the temperature was lower than the optimal value, the LA yield and LA production rate of immobilized cells increased slowly with the increase in temperature. As the temperature further increased, the LA yield and LA production rate of immobilized cells slightly decreased, but they were all maintained at a high level. However, temperature changes have a more significant effect on the LA yield and LA production rate of free cells (Fig. 4c). This result indicated that the immobilized cells had higher heat stability, but the free

Table 5 The comparison of LA production of CS-film-coated SA-PVA immobilized L. pentosus cells (SA-PVA-CS) and normal SA-PVA immobilized L. pentosus cells (SA-PVA) at 5\% level of significance

\begin{tabular}{lll}
\hline Cell type & LA yield, $g / g$ fructose & $\begin{array}{l}\text { LA production } \\
\text { rate, } g /(L \times h)\end{array}$ \\
\hline SA-PVA-CS & $0.967 \pm 0.006$ & $2.426 \pm 0.018$ \\
SA-PVA & $0.942 \pm 0.008$ & $2.203 \pm 0.025$ \\
Percentage of increment & $2.7 \%$ & $10.1 \%$ \\
t statistic of increment & 4.33 & 12.54 \\
Degree of freedom & 3 & 3 \\
p value & $0.023 \wedge$ & $0.001^{\wedge}$
\end{tabular}

$\wedge$ Significant at $5 \%$ level
Table 6 The comparison of LA production of CS-film-coated SA-PVA immobilized $L$. pentosus cells (SA-PVA-CS) and free $L$. pentosus cells at $5 \%$ level of significance

\begin{tabular}{lll}
\hline Cell type & LA yield, $g / g$ fructose & $\begin{array}{l}\text { LA production } \\
\text { rate, } g /(L \times h)\end{array}$ \\
\hline SA-PVA-CS & $0.967 \pm 0.006$ & $2.426 \pm 0.018$ \\
Free & $0.915 \pm 0.010$ & $1.637 \pm 0.023$ \\
Percentage of increment & $5.7 \%$ & $48.4 \%$ \\
t statistic of increment & 7.72 & 46.79 \\
Degree of freedom & 3 & 3 \\
p value & $0.002^{\wedge}$ & $<0.001^{\wedge}$ \\
\hline
\end{tabular}

$\wedge$ Significant at $5 \%$ level

cells had a higher heat sensitivity (John et al. 2007). The different trends of LA yield and production rate of two types of immobilized cells in the range of higher temperature were also observed, which indicated that the performance of heat resistance was related to the properties and concentrations of gel materials.

\section{Comparison of $L A$ yield and $L A$ production rate of three types of cells at different $\mathrm{pH}$}

The effect of $\mathrm{pH}$ on LA yield and LA production rate on three types of cells was similar (Fig. 5a-c). It indicated that the effect of $\mathrm{pH}$ was only related to the enzyme activity of cells and the level of product inhibition caused by the undissociated LA (Gonçalves et al. 1997), and it has no relationship with the type and concentration of gel materials. However, free cells still have more significant $\mathrm{pH}$ sensitivity.

\section{Kinetic analysis}

For batch fermentation, the cell growth rate was expressed by Eq. (7) based on the Malthus Equation (Liu 2020).

$$
r_{X}=\frac{d X}{d t}=\mu_{\mathrm{Gnet}} X=\left(\mu_{G}-k_{d}\right) X,
$$

where $r_{X}, X, t, \mu_{\mathrm{Gnet}}, \mu_{G}$, and $k_{d}$ represent cell growth rate, cell concentration, fermentation time, net specific cell growth rate, specific cell growth rate, and cell death rate, respectively.

The production rate was expressed by Eq. (8).

$$
r_{P}=\frac{d P}{d t}=\mu_{P} X
$$

where $r_{P}, P$, and $\mu_{P}$ represent production rate, product (LA) concentration, and specific production rate, respectively. 

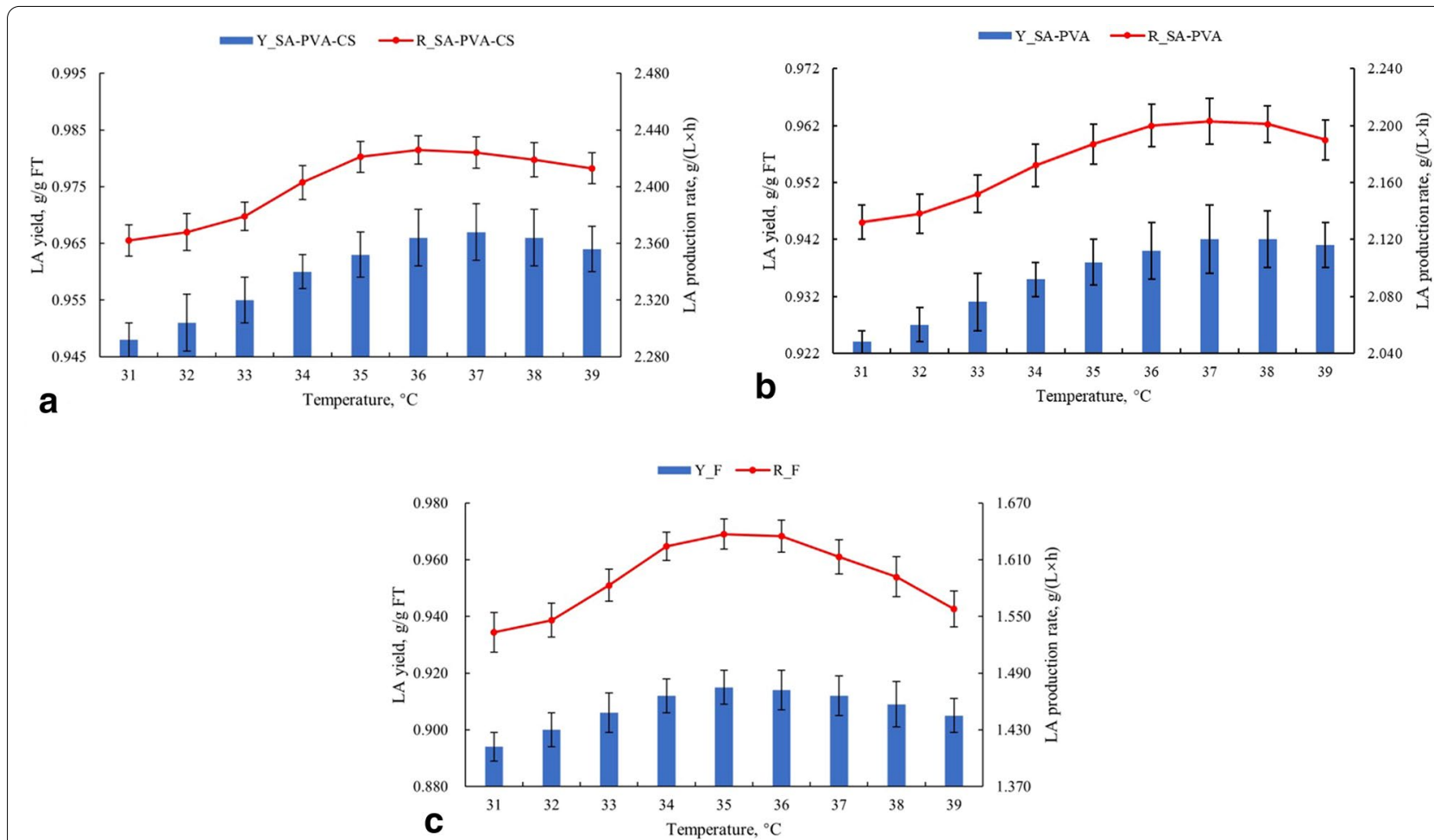

Fig. 4 The effect of temperature on LA yield and LA production rate of a CS film-coated SA-PVA immobilized cells, b normal SA-PVA immobilized cells, and $\mathbf{c}$ free cells. Other conditions were controlled as the optimal conditions for each cell type

The substrate (fructose) consumption rate was expressed by Eq. (9) based on the mass balance principles.

$$
r_{S}=\frac{d S}{d t}=-\left(\frac{\mu_{G}}{Y F_{X / S}}-\frac{\mu_{P}}{Y F_{P / S}}\right) X
$$

where $r_{S}, S, Y F_{X / S}$ and $Y F_{P / S}$ represent the substrate consumption rate, substrate concentration, yield factor of cell biomass, and yield factor of product, respectively. The yield factors were independent of the substrate concentration (Buyondo and Liu 2013).

For $\mu_{G}$, the expression was modified based on the Monod Equation and Verhulst model as Eq. (10) to show a restricted cell growth rate due to the limited nitrogen source, air flow rate. The space for cell growth was also limited for immobilized cells.

$$
\mu_{G}=\frac{\mu_{\mathrm{Gmax}} S}{K_{S}+S}\left(1-\frac{X}{X_{\max }}\right)
$$

where $\mu_{\operatorname{Gmax}}, K_{S}$, and $X_{\max }$ represent maximum cell growth rate, kinetic constant of cell growth, and predicted maximum cell concentration.

Therefore, the kinetic model of $r_{X}$ was obtained as Eq. (11).

$$
r_{X}=\left[\frac{\mu_{\mathrm{Gmax}} S}{K_{S}+S}\left(1-\frac{X}{X_{\max }}\right)-k_{d}\right] X .
$$

For $\mu_{P}$, the expression was modified based on the Michaelis-Menten equation as Eq. (12) to show an inhibition on LA productivity caused by the combined effects of undissociated and dissociated LA on cytoplasm (Gonçalves et al. 1997).

$$
\mu_{P}=\frac{\mu_{\mathrm{Pmax}} S}{\left(K_{P}+S\right)\left(1+\frac{P}{K_{I}}\right)},
$$

where $\mu_{\mathrm{pmax}}$ represents maximum production rate. Whereas $K_{P}$ and $K_{I}$ represent kinetic constant of product synthesis and inhibition, respectively.

Therefore, the kinetic model of $r_{P}$ was obtained as Eq. (13).

$$
r_{P}=\frac{\mu_{\mathrm{Pmax}} S}{\left(K_{P}+S\right)\left(1+\frac{P}{K_{I}}\right)} X .
$$

The expression of $r_{s}$ was subsequently obtained as Eq. (14). 

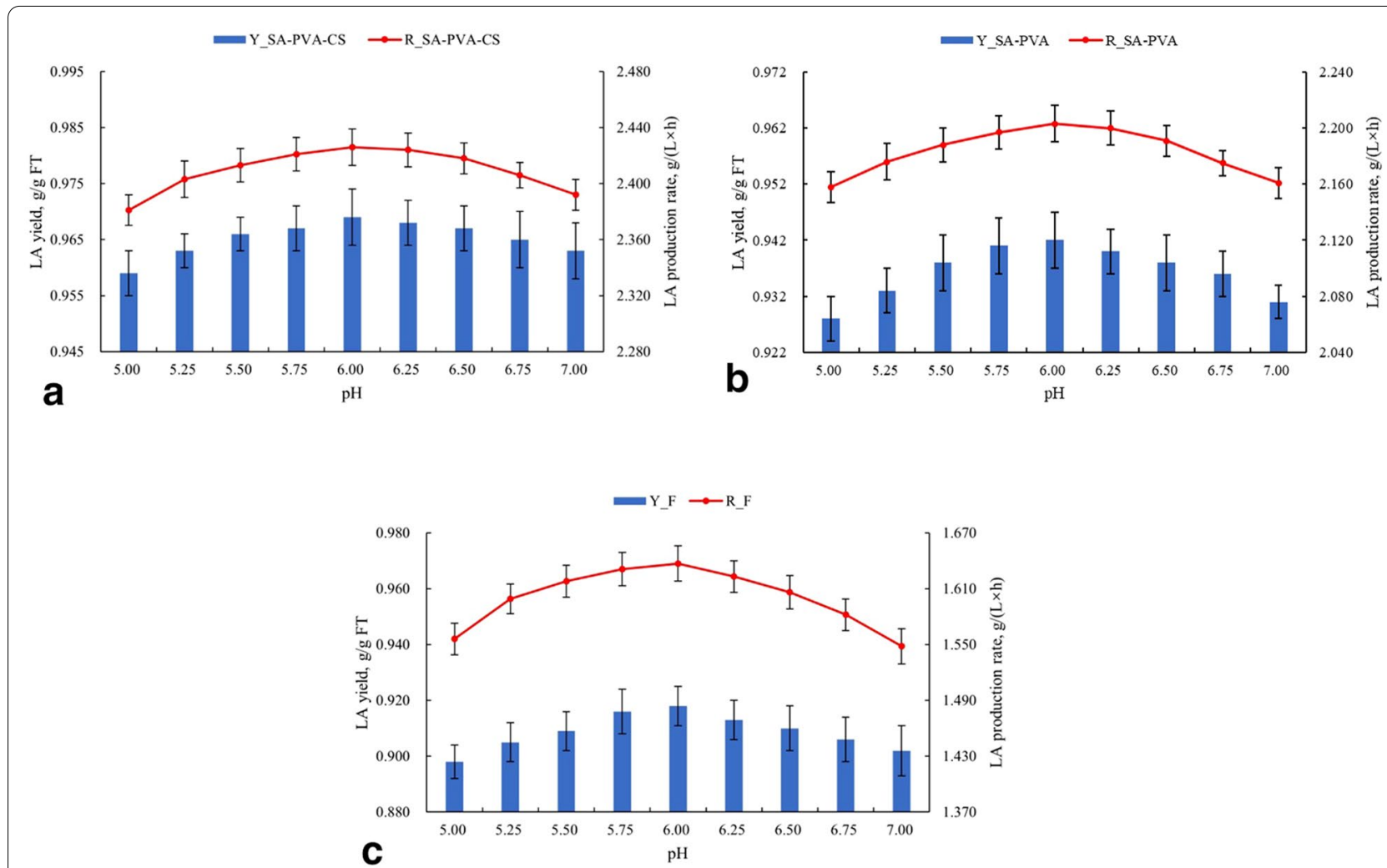

Fig. 5 The effect of $\mathrm{pH}$ on LA yield and LA production rate of a CS film-coated SA-PVA immobilized cells, $\mathbf{b}$ normal SA-PVA immobilized cells, and $\mathbf{c}$ free cells. Other conditions were controlled as the optimal conditions for each cell type

$$
\begin{aligned}
r_{S}= & -\left\{\left[\frac{\mu_{\mathrm{Gmax}} S}{K_{S}+S}\left(1-\frac{X}{X_{\max }}\right)\right] \frac{1}{Y F_{X / S}}\right. \\
& \left.+\frac{\mu_{\mathrm{Pmax}} S}{\left(K_{P}+S\right)\left(1+\frac{P}{K_{I}}\right) Y F_{P / S}}\right\} X .
\end{aligned}
$$

The kinetic parameters were obtained based on Eqs. (11), (13), (14) (Table 7). Compared to the free cells, the immobilized cells had a lower $\mu_{\mathrm{Gmax}}$, which led to a lower rate of cell growth than that of free cells. Although the growth of immobilized cells is further inhibited compared to free cells, the substrate is still consumed at a high rate for LA synthesis. Therefore, when both cell growth and LA synthesis are involved, the $K_{S}$ of immobilized cells is still much smaller than that of free cells. The lower $X_{\max }$ of immobilized cells also reflected the growth inhibition of cells. The immobilized cells also had higher $\mu_{P \max }$ and lower $K_{P}$, which indicated that the immobilized cells had a higher metabolic activity, and it takes less time to reach the maximum metabolic rate, resulting in a higher overall rate of LA synthesis. The $K_{I}$ values of the three types of cells
Table 7 Kinetic parameters of batch fermentation by CS filmcoated SA-PVA immobilized cells (SA-PVA-CS), normal SA-PVA immobilized cells (SA-PVA), and free cells (Free)

\begin{tabular}{llllr}
\hline Parameter & Unit & \multicolumn{2}{l}{ Value } \\
\cline { 3 - 5 } & & SA-PVA-CS & SA-PVA & \multicolumn{1}{l}{ Free } \\
\hline$\mu_{G \max }$ & $\mathrm{h}^{-1}$ & 0.1187 & 0.1420 & 0.2732 \\
$K_{S}$ & $\mathrm{~g} / \mathrm{L}$ & 0.2842 & 0.1834 & 3.1813 \\
$X_{\max }$ & $\mathrm{g} / \mathrm{L}$ & 3.1321 & 5.6815 & 10.7424 \\
$\mu_{P \max }$ & $\mathrm{h}^{-1}$ & 187.2759 & 127.1298 & 53.1298 \\
$K_{P}$ & $\mathrm{~g} / \mathrm{L}$ & 28.2213 & 50.0217 & 61.8285 \\
$K_{l}$ & $\mathrm{~g} / \mathrm{L}$ & 0.7534 & 0.7161 & 0.7843 \\
$Y F_{P / S}$ & $\mathrm{~g} / \mathrm{g}$ & 1.8193 & 1.4653 & 1.2958 \\
$Y F_{X / S}$ & $\mathrm{~g} / \mathrm{g}$ & 0.0327 & 0.1195 & 0.4893 \\
$K_{d}$ & $\mathrm{~h}^{-1}$ & - & - & 0.0063 \\
\hline
\end{tabular}

were similar, which indicated that the levels of product inhibition were similar due to their close values of optimized $\mathrm{pH}$. The higher $Y F_{P / S}$ and lower $Y F_{X / S}$ of immobilized cells indicated a higher efficiency of substrate conversion to LA. The $k_{d}$ of immobilized cells was negligible compared to that of free cells, which also indicated higher cell viability of immobilized cells. The 

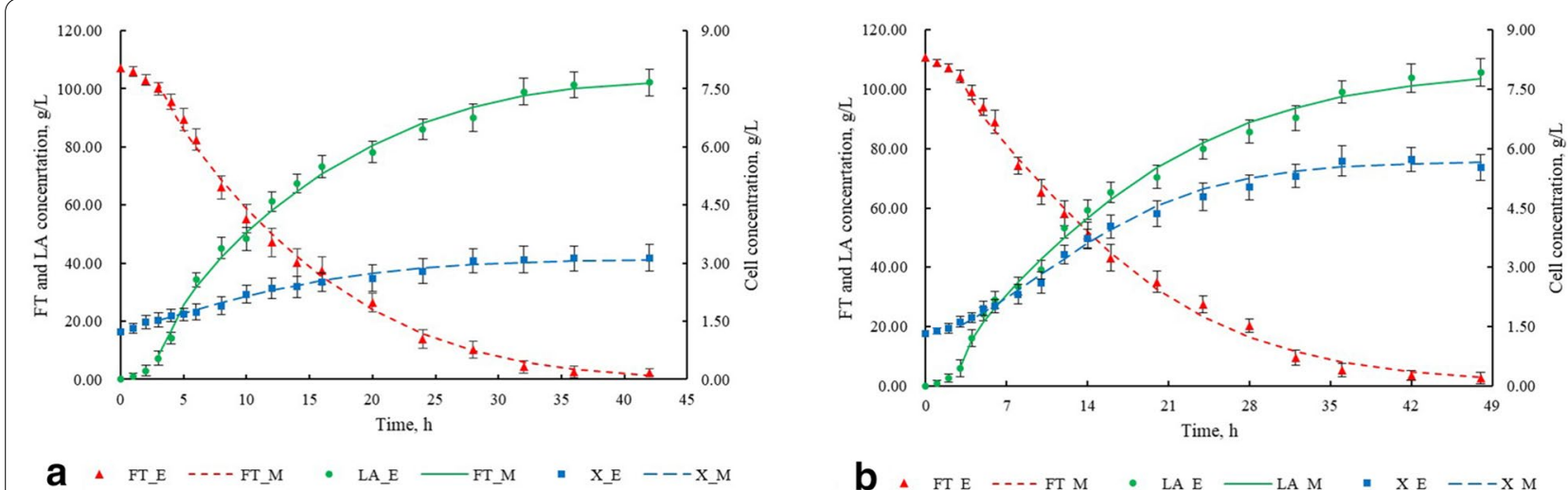

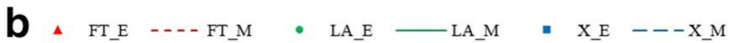

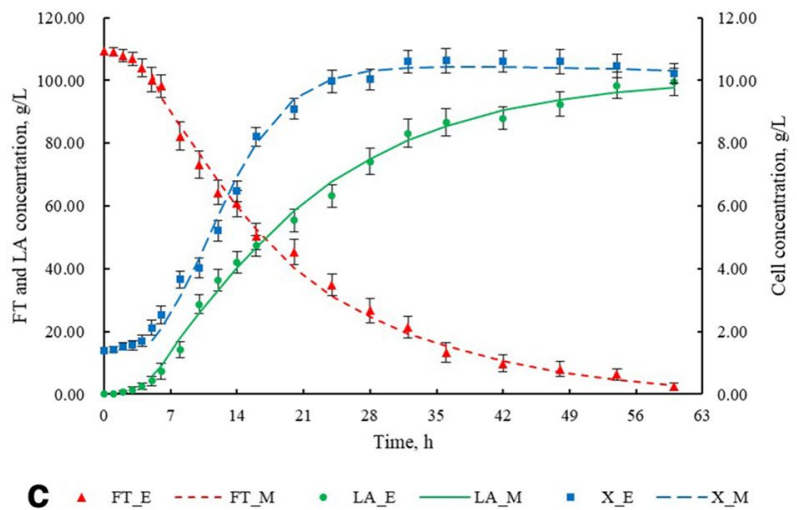

Fig. 6 The experimental results and model prediction results of a CS film-coated SA-PVA immobilized cells, $\mathbf{b}$ normal SA-PVA immobilized cells, and c free cells. F_E, LA_E, and X_E represent the experimental data of FT concentration, LA concentration, and cell concentration, respectively. F_M, LA_M, and X_M represent the model-predicted data of FT concentration, LA concentration, and cell concentration, respectively

better fermentation performance of CS film-coated SAPVA immobilized cells compared to that of normal SAPVA immobilized cells mainly resulted from the higher overall cell viability due to the better performance of cell encapsulation. In Eqs. (11), (13), and (14), the influence of the substrate concentration on the rates of cell growth and LA synthesis can be intuitively reflected. By continuous integration, the concentrations of cell and LA at any time point in the fermentation period can be obtained simultaneously.

The fermentation periods of CS film-coated SA-PVA immobilized cells, normal SA-PVA immobilized cells, and free cells were $42 \mathrm{~h}, 48 \mathrm{~h}$, and $60 \mathrm{~h}$, respectively (Fig. 6a-c). The fermentation performance of the three cell types mainly depends on their growth and metabolic activity. Immobilized cells have lower growth activity but higher metabolism levels than free cells. Compared with normal SA-PVA immobilized cells, the application of CS film further inhibited the activity of cell growth and improved efficiency of cell metabolism, which were also reflected by the kinetic parameters of two types of immobilized cells. The kinetic models of fructose consumption, LA synthesis, and cell growth have high correlation coefficients (Table 8). These models can be used to mathematically predict the fermentation performance of three cell types from fructose with high accuracy and reasonability.

\section{Repeated batch fermentation}

The CS film-coated SA-PVA immobilized cells could maintain high LA yield and production rate in nine batches, which implied these immobilized cells had good

Table 8 Correlation coefficients $\left(R^{2}\right)$ between the experimental results and model prediction results of CS film-coated SA-PVA immobilized cells (SA-PVA-CS), normal SA-PVA immobilized cells (SA-PVA), and free cells (Free)

\begin{tabular}{llll}
\hline Cell type & FT concentration & LA concentration & Cell concentration \\
\hline SA-PVA-CS & 0.9868 & 0.9955 & 0.9939 \\
SA-PVA & 0.9920 & 0.9949 & 0.9930 \\
Free & 0.9909 & 0.9935 & 0.9942 \\
\hline
\end{tabular}


Table 9 Performance of repeated batch fermentation by CS film-coated SA-PVA immobilized cells (SA-PVA-CS) and normal SA-PVA immobilized cells (SA-PVA)

\begin{tabular}{|c|c|c|c|c|}
\hline \multirow[t]{2}{*}{ Batch } & \multicolumn{2}{|l|}{ SA-PVA-CS } & \multicolumn{2}{|l|}{ SA-PVA } \\
\hline & $\begin{array}{l}\text { LA yield } \\
Y_{L A} g / g F T\end{array}$ & $\begin{array}{l}\text { LA production rate } \\
R_{L A} g /(L \times h)\end{array}$ & $\begin{array}{l}\text { LA yield } \\
Y_{L A^{\prime}} g / g F T\end{array}$ & $\begin{array}{l}\text { LA production rate } \\
R_{L A^{\prime}} g /(L \times h)\end{array}$ \\
\hline 1 & $0.967 \pm 0.009$ & $2.426 \pm 0.018$ & $0.942 \pm 0.008$ & $2.203 \pm 0.025$ \\
\hline 2 & $0.971 \pm 0.006$ & $2.431 \pm 0.017$ & $0.946 \pm 0.007$ & $2.207 \pm 0.021$ \\
\hline 3 & $0.960 \pm 0.011$ & $2.415 \pm 0.021$ & $0.947 \pm 0.011$ & $2.210 \pm 0.019$ \\
\hline 4 & $0.964 \pm 0.008$ & $2.417 \pm 0.021$ & $0.949 \pm 0.012$ & $2.212 \pm 0.021$ \\
\hline 5 & $0.966 \pm 0.007$ & $2.422 \pm 0.022$ & $0.946 \pm 0.008$ & $2.208 \pm 0.018$ \\
\hline 6 & $0.973 \pm 0.005$ & $2.427 \pm 0.019$ & $0.943 \pm 0.006$ & $2.207 \pm 0.017$ \\
\hline 7 & $0.963 \pm 0.010$ & $2.423 \pm 0.021$ & $0.941 \pm 0.009$ & $2.203 \pm 0.019$ \\
\hline 8 & $0.962 \pm 0.009$ & $2.411 \pm 0.021$ & $0.941 \pm 0.007$ & $2.206 \pm 0.023$ \\
\hline 9 & $0.959 \pm 0.006$ & $2.409 \pm 0.023$ & $0.946 \pm 0.008$ & $2.206 \pm 0.024$ \\
\hline 10 & $0.953 \pm 0.007$ & $2.401 \pm 0.026$ & $0.943 \pm 0.010$ & $2.201 \pm 0.018$ \\
\hline 11 & $0.947 \pm 0.008$ & $2.394 \pm 0.022$ & $0.938 \pm 0.012$ & $2.194 \pm 0.019$ \\
\hline 12 & $0.942 \pm 0.009$ & $2.375 \pm 0.025$ & $0.934 \pm 0.001$ & $2.182 \pm 0.024$ \\
\hline 13 & $0.939 \pm 0.005$ & $2.361 \pm 0.024$ & $0.927 \pm 0.008$ & $2.169 \pm 0.026$ \\
\hline 14 & - & - & $0.921 \pm 0.009$ & $2.157 \pm 0.022$ \\
\hline 15 & - & - & $0.913 \pm 0.006$ & $2.146 \pm 0.023$ \\
\hline
\end{tabular}

reusability (Table 9). The significant decrease in LA yield and production rate started from the $10^{\text {th }}$ batch, and the breakage of the beads was observed in the 13th batch. The normal SA-PVA immobilized cells could maintain a high LA yield and production rate in ten batches, and the breakage of the beads was observed in the 15th batch. It could be confirmed that both CS film-coated SA-PVA immobilized cells and normal SA-PVA immobilized cells have excellent mechanical stability to avoid the bead breakage due to the cell growth and continuous stirring. Compared with normal SA-PVA immobilized cells, the slightly lower mechanical strength of CS film-coated SAPVA immobilized cells might be due to the lower optimal PVA concentration. A higher concentration of PVA can effectively prevent the reduction in mechanical strength caused by the bead expansion in the repeated batch fermentation process. However, the LA yield and production rate of CS film-coated SA-PVA immobilized cells in each batch was always much higher than that of normal SA-PVA immobilized cells.

\section{Conclusion}

Under the optimal conditions, the highest LA yield and production rate of CS film-coated SA-PVA immobilized cells can be obtained as $0.966 \pm 0.006 \mathrm{~g} / \mathrm{g}$ fructose and $2.426 \pm 0.018 \mathrm{~g} /(\mathrm{L} \times \mathrm{h})$, respectively, which have better fermentation performance than that of normal SA-PVA immobilized cells and free cells. The errors of LA yield and LA production rate were $-0.5 \%$ and -0.2 , respectively, which confirms the accuracy and reliability of the prediction for fermentation performance and the estimation for optimal conditions. The immobilized cells have excellent heat stability, while the free cells have higher sensitivity to temperature and $\mathrm{pH}$. The kinetic parameters can effectively describe the fermentation performance of different types of cells. The kinetic models of CS film-coated SA-PVA immobilized cells can be used to describe the tendency of fructose consumption, LA production, and cell growth during the complete fermentation period. The CS film-coated SA-PVA immobilized cells with excellent mechanical strength have good reusability for repeated batch fermentation.

\section{Abbreviations}

ANOVA: Analysis of variance; ATCC: American Type Culture Collection; CS: Chitosan; EMP: Embden-Meyerhoff-Parnas; FT: Fructose; LA: Lactic acid; LAB: Lactic acid bacteria; MRS: De Man, Rogosa and Sharpe; 1 H NMR: Proton nuclear magnetic resonance; OD: Optical density; PK: Pentose phosphoketolase; PLA: Polylactic acid; PVA: Polyvinyl alcohol; RSM: Response surface methodology; SA: Sodium alginate.

\section{Annotation of kinetic parameters \\ $\mu_{G m a x}$ : Maximum cell growth rate; $K_{s}$ : Kinetic constant of cell growth; $X_{\max }$ : Predicted maximum cell concentration; $\mu_{\mathrm{Pmax}}$ : Maximum production rate; $K_{p}$ : Kinetic constant of product synthesis; $K_{j}$ : Kinetic constant of product inhibi- tion; $Y F_{P / S}$ :Yield factor of cell biomass; $Y F_{X / S}$ : Yield factor of product; $K_{d}$ : Cell death rate.}

\section{Acknowledgements}

The authors thank SUNY College of Environmental Science and Forestry for the help and support in this study.

\section{Author contributions}

$J W, H G$, and $S L$ are the primary contributors of this work. JH, SJ, SH, XC, and $\mathrm{HL}$ participated in studies and manuscript preparation. $\mathrm{XB}$ and $\mathrm{MH}$ provide 
important technical supports. $\mathrm{HL}, \mathrm{YL}, J \mathrm{Q}$, and $\mathrm{RY}$ supported in the manuscript preparation. All authors read and approved the final manuscript.

\section{Funding}

Not applicable.

\section{Availability of data and materials}

All data obtained or analyzed during this study are included in this article and available from the corresponding author.

\section{Declarations}

\section{Ethics approval and consent to participate}

Not applicable.

\section{Consent for publication}

The publication of the paper has been agreed by the authors.

\section{Competing interests}

The authors declare that they have no potential conflicts of interest.

\section{Author details}

${ }^{1}$ Department of Chemical Engineering, SUNY College of Environmental Science and Forestry, Syracuse NY13210, USA. ${ }^{2}$ The Center for Biotechnology and Interdisciplinary Studies (CBIS) at Rensselaer Polytechnic Institute, Troy NY12180, USA. ${ }^{3}$ California State University, Los Angeles (CSULA), Los Angeles, CA 90032, USA. ${ }^{4}$ Department of Biomedical Engineering, City University of Hong Kong, Hong Kong 999077, China.

Received: 15 January 2021 Accepted: 30 March 2021

Published online: 07 April 2021

\section{References}

Abd Alsaheb RA, Aladdin A, Othman NZ, Abd Malek R, Leng OM, Aziz R, El Enshasy HA (2015) Lactic acid applications in pharmaceutical and cosmeceutical industries. J Chem Pharm Res 7(10):729-735

Abdel-Rahman MA, Tashiro Y, Sonomoto K (2011) Lactic acid production from lignocellulose-derived sugars using lactic acid bacteria: overview and limits. J Biotechnol 156(4):286-301. https://doi.org/10.1016/j.jbiotec.2011. 06.017

Agarwal M, Koelling KW, Chalmers JJ (1998) Characterization of the degradation of polylactic acid polymer in a solid substrate environment. Biotechnol Prog 14(3):517-526. https://doi.org/10.1021/bp980015p

Agrawal DC, Yadav A, Kesarwani R, Srivastava ON, Kayastha AM (2020) Immobilization of fenugreek $\beta$-amylase onto functionalized graphene quantum dots (GQDs) using Box-Behnken design: Its biochemical, thermodynamic and kinetic studies. Int J Biol Macromol 144:170-182. https://doi.org/10. 1016/j.ijbiomac.2019.12.033

Bahry H, Abdalla R, Pons A, Taha S, Vial C (2019) Optimization of lactic acid production using immobilized Lactobacillus rhamnosus and carob pod waste from the Lebanese food industry. J Biotechnol 306:81-88. https:// doi.org/10.1016/j.jbiotec.2019.09.017

Bhatnagar Y, Singh GB, Mathur A, Srivastava S, Gupta S, Gupta N (2016) Biodegradation of carbazole by Pseudomonas sp. GBS. 5 immobilized in polyvinyl alcohol beads. J Biochem Technol 6(3):1003-7

Bustos G, Moldes AB, Cruz JM, Domínguez JM (2005) Influence of the metabolism pathway on lactic acid production from hemicellulosic trimming vine shoots hydrolyzates using Lactobacillus pentosus. Biotechnol Prog 21(3):793-798. https://doi.org/10.1021/bp049603v

Buyondo JP, Liu S (2013) Unstructured kinetic modeling of batch production of lactic acid from hemicellulosic sugars. J Bioprocess Eng Bioref 2(1):40-45. https://doi.org/10.1166/jbeb.2013.1037

Cazor A, Deborde C, Moing A, Rolin D, This H (2006) Sucrose, glucose, and fructose extraction in aqueous carrot root extracts prepared at different temperatures by means of direct NMR measurements. J Agric Food Chem 54(13):4681-4686. https://doi.org/10.1021/jf060144i

Dong TT, Gong JS, Gu BC, Zhang Q, Li H, Lu ZM, Lu ML, Shi JS, Xu ZH (2017) Significantly enhanced substrate tolerance of Pseudomonas putida nitrilase via atmospheric and room temperature plasma and cell immobilization. Biores Technol 244:1104-1110. https://doi.org/10.1016/j.biort ech.2017.08.039

Gao C, Ma C, Xu P (2011) Biotechnological routes based on lactic acid production from biomass. Biotechnol Adv 29(6):930-939. https://doi.org/10. 1016/j.biotechadv.2011.07.022

Gilson CD, Thomas A (1995) Ethanol production by alginate immobilised yeast in a fluidised bed bioreactor. J Chem Technol Biotechnol 62(1):38-45. https://doi.org/10.1002/jctb.280620106

Gonçalves LM, Ramos A, Almeida JS, Xavier AM, Carrondo MJ (1997) Elucidation of the mechanism of lactic acid growth inhibition and production in batch cultures of Lactobacillus rhamnosus. Appl Microbiol Biotechnol 48(3):346-350. https://doi.org/10.1007/s002530051060

Gür SD, İdil N, Aksöz N (2018) Optimization of enzyme co-immobilization with sodium alginate and glutaraldehyde-activated chitosan beads. Appl Biochem Biotechnol 184(2):538-552. https://doi.org/10.1007/ s12010-017-2566-5

Hansen G, Johansen CL, Marten G, Wilmes J, Jespersen L, Arneborg N (2016) Influence of extracellular pH on growth, viability, cell size, acidification activity, and intracellular pH of Lactococcus lactis in batch fermentations. Appl Microbiol Biotechnol 100(13):5965-5976. https://doi.org/10.1007/ s00253-016-7454-3

Jeon Y, Bissessur A, Singh P (2019) Novel immobilization techniques of Acinetobacter (V2) and Paenibacillus (D9) bacterial strains for waste oil degradation. Biotechnol Biotechnol Equip 33(1):911-20. https://doi.org/ $10.1080 / 13102818.2019 .1628663$

John RP, Nampoothiri KM, Pandey A (2007) Production of L (+) lactic acid from cassava starch hydrolyzate by immobilized Lactobacillus delbrueckii. J Basic Microbiol 47(1):25-30. https://doi.org/10.1002/jobm.200610208

Kumar MN, Gialleli Al, Masson JB, Kandylis P, Bekatorou A, Koutinas AA, Kanellaki M (2014) Lactic acid fermentation by cells immobilised on various porous cellulosic materials and their alginate/poly-lactic acid composites. Biores Technol 165:332-335. https://doi.org/10.1016/.biortech.2014.02.110

Liu S (2020) Bioprocess engineering: kinetics, sustainability, and reactor design. Elsevier

Llamas M, Magdalena JA, González-Fernández C, Tomás-Pejó E (2020) Volatile fatty acids as novel building blocks for oil-based chemistry via oleaginous yeast fermentation. Biotechnol Bioeng 117(1):238-250. https://doi.org/ 10.1002/bit.27180

Martinez FA, Balciunas EM, Salgado JM, González JM, Converti A, de Souza Oliveira RP (2013) Lactic acid properties, applications and production: a review. Trends Food Sci Technol 30(1):70-83. https://doi.org/10.1016/j.tifs. 2012.11.007

Mayo B, Aleksandrzak-Piekarczyk T, Fernández M, Kowalczyk M, Álvarez-Martín P, Bardowski J (2010) Updates in the metabolism of lactic acid bacteria. Biotechnol Lactic Acid Bacteria 5:3-3. https://doi.org/10.1002/97808 13820866.ch1

Najafpour G, Younesi H, Ismail KS (2004) Ethanol fermentation in an immobilized cell reactor using Saccharomyces cerevisiae. Biores Technol 92(3):251-260. https://doi.org/10.1016/j.biortech.2003.09.009

Olszewska-Widdrat A, Alexandri M, López-Gómez JP, Schneider R, Mandl M, Venus I (2019) Production and purification of I-lactic acid in lab and pilot scales using sweet sorghum juice. Fermentation. 5(2):36. https://doi.org/ 10.3390/fermentation5020036

Radosavljević M, Lević S, Belović M, Pejin J, Djukić-Vuković A, Mojović L Nedović V (2020) Immobilization of Lactobacillus rhamnosus in polyvinyl alcohol/calcium alginate matrix for production of lactic acid. Bioprocess Biosyst Eng 43(2):315-322. https://doi.org/10.1007/s00449-019-02228-0

Ricci A, Cirlini M, Calani L, Bernini V, Neviani E, Del Rio D, Galaverna G, Lazzi C (2019) In vitro metabolism of elderberry juice polyphenols by lactic acid bacteria. Food Chem 276:692-699. https://doi.org/10.1016/j.foodchem. 2018.10 .046

Sridevi V, Padmaja M, Sahitya A, Vardhan NH, Rao GH (2015) Application of Box-Behnken Design for the optimized production of lactic acid by newly isolated Lactobacillus plantarum JX183220 using cassava (Manihot esculenta Crantz) Flour. Biotechnol J Int. https://doi.org/10.9734/BBJ/ 2015/20236

Tang Y, Pang L, Wang D (2017) Preparation and characterization of borate bioactive glass cross-linked PVA hydrogel. J Non-Cryst Solids 476:25-29. https://doi.org/10.1016/j.jnoncrysol.2017.07.017 
Tapia MS, Alzamora SM, Chirife J (2020) Effects of water activity (aw) on microbial stability as a hurdle in food preservation. Water Activity Foods. https://doi.org/10.1002/9781118765982.ch14

Thakur A, Panesar PS, Saini MS (2018) Parametric optimization of lactic acid production by immobilized Lactobacillus casei using Box-Behnken design. Periodica Polytech Chem Eng 62(3):274-285. https://doi.org/10. 3311/PPch.11403

Vidgren V, Multanen JP, Ruohonen L, Londesborough J (2010) The temperature dependence of maltose transport in ale and lager strains of brewer's yeast. FEMS Yeast Res 10(4):402-411. https://doi.org/10.1111/j.1567-1364.2010.00627.x

Wang Z, Wang Y, Yang ST, Wang R, Ren H (2010) A novel honeycomb matrix for cell immobilization to enhance lactic acid production by Rhizopus oryzae. Biores Technol 101(14):5557-5564. https://doi.org/10.1016/j.biortech. 2010.02.064

Wang J, Huang J, Guo H, Jiang S, Zhang J, Ning Y, Fang M, Liu S (2020a) Optimization of immobilization conditions for Lactobacillus pentosus cells. Bioprocess Biosyst Eng. https://doi.org/10.1007/s00449-020-02305-9

Wang J, Huang J, Jiang S, Zhang J, Zhang Q, Ning Y, Fang M, Liu S (2020b) Parametric optimization and kinetic study of L-lactic acid production by homologous batch fermentation of Lactobacillus pentosus cells. Biotechnol Appl Biochem. https://doi.org/10.1002/bab.1994
Wang J, Huang J, Laffend H, Jiang S, Zhang J, Ning Y, Fang M, Liu S (2020c) Optimization of immobilized Lactobacillus pentosus cell fermentation for lactic acid production. Bioresour Bioprocess 7(1):1-4. https://doi.org/10. 1186/s40643-020-00305-X

Xu Z, Li S, Fu F, Li G, Feng X, Xu H, Ouyang P (2012) Production of D-tagatose, a functional sweetener, utilizing alginate immobilized Lactobacillus fermentum CGMCC2921 cells. Appl Biochem Biotechnol 166(4):961-973. https://doi.org/10.1007/s12010-011-9484-8

Zhao Z, Xie X, Wang Z, Tao Y, Niu X, Huang X, Liu L, Li Z (2016) Immobilization of Lactobacillus rhamnosus in mesoporous silica-based material: an efficiency continuous cell-recycle fermentation system for lactic acid production. J Biosci Bioeng 121(6):645-651. https://doi.org/10.1016/j. jbiosc.2015.11.010

Zhou Y, Martins E, Groboillot A, Champagne CP, Neufeld RJ (1998) Spectrophotometric quantification of lactic bacteria in alginate and control of cell release with chitosan coating. J Appl Microbiol 84(3):342-348. https://doi. org/10.1046/j.1365-2672.1998.00348.x

\section{Publisher's Note}

Springer Nature remains neutral with regard to jurisdictional claims in published maps and institutional affiliations.

\section{Submit your manuscript to a SpringerOpen ${ }^{\odot}$ journal and benefit from:}

- Convenient online submission

- Rigorous peer review

- Open access: articles freely available online

- High visibility within the field

- Retaining the copyright to your article

Submit your next manuscript at $\boldsymbol{\nabla}$ springeropen.com 